\title{
Environment and Fate: Helpless Human Beings in Sister Carrie
}

\author{
Limin Bai \\ College of Foreign Languages, Hebei United University, Tangshan 063009, China
}

\begin{abstract}
In the late 19th century, America had been experienced the development stage mass labor, mass production and urban expansion, which produced a lot of social problems. Darwinism thought human being evolved step by step and completed each other for survival. Spencer thought that this law was adapted to the society. Naturalism began to develop. Sister Carrie tells a story: a girl from the country comes to Chicago, becomes the mistress of two men, finally deserts them and carves out her own career. On surface it is immoral. In fact it, however, expresses that the society is a Jungle which decides human being, and human being has no rights to choose.
\end{abstract}

\section{Index Terms—Darwinism, Theodore Dreiser, Naturalism}

As for me life is the moil and embarrassment which the incredible power gives human beings. It doesn't allow human being to present any important ideas and this is true at least for me. One can paint a picture to enjoy himself or other. But from my point of view, he is not but a puny individual, in many mysterious and unknown things, walking around meaninglessly, along the road like the yarn, if it can be accounted as a road. In a word, from what I have witnessed I find nothing meaningful. After I experienced these things, I seemed to have encountered them, vacantly and dispiritedly.

Dreiser

When Dreiser went to American literary world, America was encountering the drastic social changes, transiting from capitalism to monopolistic capitalism. The style controlling the literary world was still the Victorian "genteel tradition". In the pastoral song of beautifying reality, Dreiser appeared all of a sudden. By his full-length works like epic, he tore the soft veil of capitalist society, exploded the elegant sermon of the upper class, and returned the original face of the society. Through all the difficulties, he opened a new prospect for the American novel and also reclaimed a path for the novelists of later generation.

Naturalism was another turn-of-the-century literary movement. Naturalism is based on social Darwinism. Darwin claims the world is a product of evolution. His theory denies the Judeo-Christian story of the creation of the universe by God in six days, as expressed in Genesis, the first book of the Bible and the semi-divinity of humankind by connecting human beings to the animal world. By the end of the civil war, northern industrialism had triumphed over southern agrarianism, and from that victory came a society based on mass labor and mass consumption. Mechanization spread rapidly as steam engines, linked to machines, displaced hand work on farms and factories. The conditions of labor changed for the use new machines, which seemed more valuable and more useful than the workers who tended them. Yet increasing numbers of Americans left the farms to seek jobs I urban factories. However periodic economic depressions, bloody strikes, increasing slums in the cities day by day and various disorders of society made some Americans realized that they did need a new philosophy to explain all of these phenomena. Therefore social Darwinism was spread to America and filled the blank of American knowledge.

Social Darwinism was derived from Darwinism. Darwin disturbed the educated world with his book The Origin of Species. Darwin claimed that change was implicit in the biological world, which over the course of an immense period the competition among living creatures for survival had provided the impetus for change from simpler and more primitive to higher and more complex forms. The world was not a finished entity created in one blinding flash but a product of evolution, of slow change over time, a process challenged simultaneously a flock of passionately held beliefs. It denied the Judeo-Christian story of the creation of the universe by God in six days, as expressed in Genesis, the first book of the Bible and the semi-divinity of humankind by connecting human beings to the animal world. Thus it made people suspicious of pre-theory and they began to consider how to put Darwinism into every scientific research field in order to discover law of evolution of other things. Therefore there were mechanical materialism and special Darwinism at the time. The famous phase by Spencer is "the fittest survival" According to Darwinism, the so-called society in fact is also a jungle, where is processing the cruel survival competition. Man has no rights to choose his life, and his fate is decided by heredity and environment, physical derives and economic circumstances. The society can not try to guarantee equality of 'result', but only equality of 'chances'. Thereby Darwinism, mechanical materialism and social Darwinism as well as French Naturalist Emile Zola influenced American Literature deeply. American Naturalism started to carve out a new approach as to imaginative fiction.

The five novelists acknowledged as the core of the Naturalist school were Hamlin Garland, Stephen Crane, Frank Norris, Jack London and Theodore Dreiser. Each in his own way tried to go beyond what he perceived as the evasions of realism. The Naturalists saw the world as a heartless interplay of deterministic forces in which men and women were 
mere objects, unable to control their own lives. The forces were economic or physical or biological, and they gripped and usually crushed--- their un-heroine, passive characters in an irresistible embrace.

Just like one sentence of our ancient poem, "too high and cold for me", from the ancient time, those who wanted to open up a new path no matter in what respect, were all lonely. Like Edwin Arlington Robinson, Dreiser seems to be doomed to become a writer without readers in the early twentieth century. His first novel Sister Carrie was almost consigned to limbo at the very beginning. People couldn't accept such a novel as disobeying the social morals and rules of that time, and more importantly, they didn't believe that the plots conformed to reality. They criticized it as follows:

Let us not believe what Dreiser has said: superman's bravery, frank intention, photographically authentic record, truth without prejudice... All of these are not reliable.

Or Although there are floods of details of details In the novel, all of these try to plead for the barbarous view.

However, just because of his acute power of observation and the truthful description of life phase, Dreiser has been accepted by readers now. Sister Carrie has become one of the great classics of American literature. By his first novel, Dreiser indicated that he was more brilliant than his peers. In the twentieth century, no other American writers like him gave the later generation so great influences, and no other novelists did so much in the aspect of liberating American literature as him

The famous novelist, James T. Farrell has ever made a pointed remark for Sister Carrie,

"Sister Carrie has a strong flavor of the late 19th century's American life. It authentically represents the feeling of the age, just like a door, making us walking into American ideology that has not existed at the present. The book is not only the documentary, but also a miserable and sad age so far that story, deduced by the cold and merciless logic. Dreiser walks ahead of the up to now, his first novel is as fresh as just being finished" (Farrell, 1945, p46).

Indeed, Sister Carrie, from the very beginning, was discussed as a moral problem. Dreiser vividly wrote all the facts into the novel: the desolate, weary and humiliating life of those people without money, social status or special abilities. With the deep sympathy, he had never claimed the right of criticizing the morals of his figures' behavior. "Dreiser not only reacts for mankind timely with full sympathy, and more importantly, despite his view' limitations he understands human beings. He is such a writer that his importance lies in what he said, but not how he said it." ( Rasscoe, 1925, p65) In Sister Carrie he often uses the hackneyed and stereotyped expressions of that time, and this can be found in the titles of every chapter. However, at the same time, he has his successful point_ he also writes some convincing argument. Dreiser's style of writing clearly indicates that he is self-taught writer. He receives little education, so he has to find something by himself. He seeks for holding and expressing the confused social order that he has known. This has been reflected in his contents and style. Happiness, misery, plaintiveness, vulgarity, spiritual pain, sentiment, also hackneyed expressions — all of these have been compromised together. He emphasizes the influence of environment and fate on human beings, thus conforming to Naturalist's view. Especially in Sister Carrie, we can understand this view.

In the twentieth century, the nation's political and imaginative path would lie on city streets. The American scene would be urban. The city was embraced by reformers who interpreted the congestion and deprivations of urban life as curable anomalies. More fundamentally many progressives and socialist--- men and women who might be called the new urban ideologist---believed that the city represented the future and offered democracy. However, Theodore Dreiser's first novel, Sister Carrie (1900) described a primitive and yet decisive account of the city's seductions and dangers. Though hid young title character, Dreiser expressed his dazzled reaction when he first came to Chicago. He wrote later of that first visit. The city was itself a strange illusion of hope and happiness with its cascade of immigrants, its daily changing skyline, its gargantuan appetites, its mingling of slaughter houses and counting houses. Chicago was perhaps the quintessential American city. This is Chicago which Caroline Meeber sought and dreamed.

No one shows any interests in Sister Carrie after its publishing. Frank Norris, accepting the novel as the agent of Doubleday publishing House, has ever said, "Remember my words: in the future Norris's fame will not reach the same height as Dreiser in American literary world." In 1902, Norris left the world. Dreiser was lost into the depressed and silent state. Sister Carrie made Dreiser suffer from such isolation and taunt. It has passed quite a few years fir him to get over it. He could not put his hand to the next novel. If Sister Carrie is a hoarse and exhausted work for protesting, if it overthrows the total beliefs, it might become the famous works for its content disregard universal condemnation. However, this novel is more profound. When it rebuilds the society from the foundation, not only does it wholeheartedly deny various basic principles, especially concerning about marriage and success, but also it explicates some common things into some newly discovered truth.

No matter how people criticize the author and the novel, one point we can not deny_ Dreiser is a serious writer, thus writing such a serious novel Sister Carrie.

Just as Dreiser (1992) said in the novel Sister Carrie,

"Among the forces which sweep and play through the universe, untutoredly, man is but a wisp in the wind. Our civilization is still in a middle stage scarcely beast, in that it is no longer wholly guided by instinct, scarcely human beings, in that it is not yet wholly guided by reason... He is becoming too wise to hearken always to instincts and desires, he is still too weak to always prevail against them." (p292-230)

Whenever I read this book, I always get a feeling__ a sense of heaviness caused by reality of life. I can't help asking myself. "If I faced the same situation Carrie, or even if I were Carrie, what should I do?" In fact what Carrie chases is the common dream of quite a few people, but the way is the key point. And also this point is the key point 
making Carrie Meeber different Edna Pontellier in Kate Chopin's The Awakening. Edna Pontellier's “awakening” to the fact of the Darwinian nature of the cosmos alerts her to her freedom from the dictates of God and gods, and also points out the gendered bias of the natural processes of life. To think of the children, and further to submit oneself fully to Darwin's ideologies of survival, is ultimately to give oneself over to a natural process which we have little control and which ultimately controls us. Darwinism offers only an illusory freedom. A world without deities seems to offer the possibility to reshape our lives at will: this is what Edna believes is open to her at first. However, she finally finds that the door into the world is locked and she has no key only because she is a female. The path out of this dilemma is to reassert control in the only way we know how: through taking our own life. Edna insists that she would give her life for her children; but she wouldn't give herself...", and she does not want anything but her own way of living. The Darwinian sea, where all life began, is also the Darwinian natural impulses that demand that women should be the recreators of the species. The sea is the representative of that character and sexuality here. And here the return to the sea maybe finally overwhelms and engulfs Edna, while Edna still bravely swims in the sea finally in the end of the novel as a rebellion for her feminine freedom. Edna's death is as natural as her subordinate position in society, which doesn't mean she was punished to die due to the social morals. Her death is a celebration of Darwinian self. Carrie Meeber, however, is quite different from Edna Pontellier. Carrie naturally follows her heart and her dream without a clear awakening in her mind, and she just chooses her life according to what choices life gives her and naturally she realizes her dream unconsciously. Carrie's way makes those so called moral people feel immoral. Maybe sometimes many things are said easier than done and in some sense, it is not easy to simply divide them into right or wrong. Just as Dreiser (1992) said in the novel Sister Carrie,

"Man has not yet comprehended the dreamer any more than he has the ideal. For him the laws and morals of the world are unduly severed. Ever hearkening to the sound of beauty, straining for the flash of its distant wings, he watches to follow wearying his feet in traveling. So watched Carrie, so followed, rocking and singing. "(p380)

Now let us walk into Carrie's world together.

At the very beginning, Carrie Meeber has been on the train to Chicago. She is a young small-town woman and comes to Chicago to help earn some money for her poor family. She finds work difficult to get, at the same time, factory work, she quickly finds, will yield only shabbiness and physical pain. Because of her illness, she loses her only job. Meanwhile, she is forced to face such choices: one is to find another job; the other is to go back to hometown. Carrie doesn't want to go back in fact. Carrie lingers a day on the street. At the time, she meets Drouet, whom she meets first on the train. the novel's plots come into another period after Carrie becomes Drouet's mistress and then meets Hurstwood. Carrie and Hurstwood are the two key figures of the novel. After they eloped together to New York, Carrie carves out her own career, while Hurstwood slides into failure. He becomes worse and worse. At last he commits suicide. Dreiser has described every plot with great details. Step by step, Dreiser suggests to his readers that environment determines everything. Human beings are only divided by strong or weak and are driven by their instinct. They have no rights to choose.

Dreiser believes "Environment is a kind of subtle and dominant power, which and desire together play a role. In Sister Carrie there are two main environments. One is Chicago_— an industrial big city; the other is New York- a developed metropolis. Let us first look at Chicago of that time.

"With its strange illusion of hope and happiness, with its cascade of immigrants, its daily changing skyline, its gargantuan appetite, its mingling of slaughter houses and counting house, Chicago was the quit essential American city." (Lewis, 1973, p 45)

"Hail, Chicago! First of the daughters of the new world." (Lewis, 1973, p 56) This is the dazzled reaction when Dreiser came to Chicago for the first time, while this is also the first city where Carrie came.

In Chicago, Drouct is a traveling salesman. Money can be got easily and he knows how to use it to reach his aim. He dresses in fashion, and has full desire for woman. However on Carrie, what he loses is only money, because at the very beginning, he just has the sexual passion for Carrie. Accidentally, he doesn't sink himself so deep. In chapter Twelve, Droute is such a person who doesn't have a long time interest for anything. He merely has unusual and quite individual beauty.He has never put women on his deep heart. When he goes out on business, he will forget Carrie totally. Maybe on his way to Chicago, he thinks of her. Droute's character is a typical example. Such character results from that age. At the same time, just because of this, Carrie's leaving doesn't affect him so much, maybe just as one of women he has ever known will not contact with him.

As for Carrie, in Chicago, she has to choose from the following two respects rationally. Whether she continues to take herself as cheap labor force without special skills in the market of Chicago, using her virgin body to trudge on the cold windy street wearing the cold and cheap shoes with water pervading, or to satisfy Droute's lust to become the cost-higher goods? Under the later condition, although she loses her chastity, she can get the warm enough clothes against freezing coldness. Dreiser doesn't urge Carrie to make her choices. He just faithfully describes the material ease later she gets and her unsatisfied spiritual longing. Common people all first chase simple happiness. Then who is Carrie? Carrie is only an ordinary countryside girl without special talents or peculiar origin. Her only advantage is her good-looking. Supposed such a given her no choices. She happens to know Droute on the train. Though Droute is warm-hearted but with harbor malicious intentions, she becomes his mistress. This can not be simply accounted as Carrie's choices. Chicago chooses Carrie in his way. This is the choice of the environment Chicago. 
Let us see New York, another existing environment. Different environments need different human beings, and create different human beings. When the second man of Carrie's life, Hurstwood eloped to New York with Carrie, their fates are quite different.

Hurstwood actually reflects a kind of social function and a beautified saloonkeeper. His total life develops from the social position — the manager of a luxurious bar of Chicago. He is smooth and well behaved. All of these seem to be his nature; however, it results from his character. But his characters result from his vocation. This result affects his generation with bitterness and tragedy. Chicago is a newly developing city and Hurstwood belongs to this kind of place. A person like him going to New York is bound to face failure, because New York is a quite developed place. Famous and rich people are here and there. Therefore his desire for is not the only reason of his declining and his tragic degeneration, that is to say, in Chicago Hurstwood is the strong; in New York he becomes the weak and this is decided by environment but not by himself. Human beings can not escape himself and his own character. Once he abandons his own social part in Chicago, Hurstwood's tragedies happen one by one. That proves that environment decides man and even his character. Man is puny when they face the whole society.

What's more, originally hurstwood is a ration man. However, there is a detail about the money-locker Hurstwood just happen to find the money-locker unlocked, he gets the money. When his ration controls him, he changes his mind and wants to put it back. While at this time, the money-locker has been locked by itself. This matter, he can not clearly explain to his boss. Whether willing, he has become a thief. This detail proves that desire can make human beings lose ration, and human beings are the victim of the fate.

Let us re-consider Carrie. In fact, isn't she a tragic figure? When she comes to her sister's home and experiences kinds of reined and poor environment, her hopes begin to break. When she wants to find a job to survive, she suffers a lot. Next she gradually finds the man whose mistress she becomes doesn't want to marry her at all. Her spiritual struggles about whether living with Drouet or not, and she also silently accepts the life philosophy disobeying with her original religious and moral education. Before Hurstwood appears, she has been accustomed to endure all of these. She knows clearly she would live a lonely and poor life after Drouet leavers her. Later Hurstwood's interest and attraction for her makes her dying heart glow again and rebuild her confidence. At first it is such confidence and spiritual power make her able to dominate Drouet. She finally is a winner, because Hurstwood's desire feels dishearted at and end. If we say there are some faults in the portrayal of the character, Carrie, I think the author should give more psychological description of the character. However, one point that is worth mentioning is that the author has given us a perplexed picture to let us find the route sign. "Hurstwood's suicide is followed by concluding meditation, a vague sigh of discontent that is untouched by remorse." (Lewis, 1973, p31) This sentence seems to tell us that Carrie is still unsatisfied. In reality, Carrie is a seeker, a dreamer at the very beginning, but she is also perplexed about herself. Her every step is facilitated by the chances that environment and fate give her. She just mechanically reacts. This also indicates that one who only can feel but can not infer, merely can chase "beauty" by a roundabout road. She is often disappointed and depressed, but she still waits for comfortable and happy life becoming reality. She still continues to live in a dream.

Caroline Meeber, a girl from countryside, comes to Chicago to seek everything she dreamed. But factory work, she quickly finds, will yield only shabbiness and physical pain. She becomes the mistress of two men in turn, the first a glib traveling salesman, the second a saloon manager named Hustwood, who sacrifices his family and reputation to run off with her to New York. The consequence of Carrie's immorality is not punishment or death but a well-paid job on New York stage. It is Hustwood not Carrie, who slides into failure and despair and finally takes his own life by turning on the gas in a flophouse room. Hustwood's suicide is followed by Carrie's concluding meditation, a vague sigh of discontent that is untouched by remorse, though Dreiser at last tells us that Carrie will never be self-indulgent and satisfied.

Sister Carrie is a serious novel or to be exact, a tragedy. No matter Carrie, Drouet and Hurstwood, everyone according to his own fate and character lives through their life. On the surface Carrie is a weak woman, but she makes good use of all the things that fate gives her. From this angle, she is strong, just as Dreiser (1992) said in his another novel "The Financier",

"We are all born in a cruel and bitter world... Who can solve the unfair problems?... someone is born with talents and has the will, power to chase wealth, while someone lacks and is weak,...Strong or weak- this is the key point, the answer."(P78-83)

\section{REFERENCES}

[1] Alfred Kazin, (1942). On Native Grounds. Los Angeles: Back Bay Press.

[2] Burton Rasscoe. (1925). Theodore Dreier. Philadelphia: Mike Brade Company. p65.

[3] Chopin. Kate. (1993). The Awakening. New York: Dover Publication. Inc.. 1993

[4] Farrell. (1945). Dreiser's Sister Carrie. New York: Pioneer Publishing House. p46.

[5] Michael. (1976). Anthology of American Literature Macmillan. New York: Publishing Company.

[6] R.W.B.Lewis. Robert Penn. (1973). Modernists and Muckakers. New York: St.Martin Press. p31-56.

[7] Theodore Dreiser. (1992). Financier. Beijing: Foreign Language Teaching and Research Press. p78-83.

[8] Theodore Dreiser. (1992). Sister Carrie. Beijing: Foreign Language Teaching and Research Press. p292-380.

[9] Thomas King Whipples. (1928). Spoksmen: Modern Writer and American Life. Boston: Abotton Company. 
Limin Bai was born in Shenyang, China in 1977. She received her master's degree in English Language and Literature from Nankai University, Tianjin in 2007.

She is currently a lecturer in the College of Foreign language, Hebei United University, Tangshan, China. Her research interests include American and British literature, culture, translation and English education. 